\title{
Does Strategic Planning Matter in Enhancing Performance of Zakah Organization? Some Insights from Zakah Management in Indonesia
}

\author{
Rahmatina A. Kasri and Niken I. S. Putri \\ University of Indonesia
}

\begin{abstract}
The paper aims to explore strategic planning practices of zakah organizations in Indonesia and their impacts on the organizational performance. It uses qualitative research approach with semi-structured interviews and a quantitative approach based on financial data from the organizations. The study found several interesting findings. First, from mission statement analysis, different zakah organizations seem to have different idealized views and focus on achieving either particular organizational characteristics or organizational targets/outcomes. Second, the strategic planning processes tend to follow the "by-design" and the "by-flow" strategies which are implemented in all zakah agencies regardless of its type. However, it is notable that only the non-government zakah agencies were flexible enough to run programs based on recommendation of the zakah payers. Third, in terms of performance, it is found that corporate zakah agency has the highest collection capacity, while the private zakah agency has the highest distributional capacity. Based on the findings, it is suggested that the zakah organizations should focus on their targets/outcomes and properly design their programs. It is also argued that all zakah agency has formulated sound mission statements and it is reflected well in the organizational capacity. This implies that there is a positive relationship between strategic planning and organizational performance.
\end{abstract}

Keywords: Zakat, Strategic Management, Zakah organization

\section{INTRODUCTION}

Derived from Arabic words, linguistically, zakah means 'growth,' 'increase,' or 'purity' of wealth. When applied to a person, it means to 'to improve' or 'to make better' (Al Qardawi, 2000). It is stipulated in the Quran that zakah is intended only for eight groups of recipients, known as the eight ashnaf, in which the two prioritized groups are the poor and needy. This implies that zakah is primarily aimed to eradicate poverty by redistributing income as well as stimulate growth and production among previously impoverished society (Kasri, 2016). The poverty eradication objective of zakah institution is reflected in the distribution of zakah to the poor and needy. However, as zakah management institutions have become formal non-profit organizations in many countries, the objective should not only be reflected by the amount and velocity of zakah distribution, but also in the strategic management and performance of the organizations.

Strategic management is started with the establishment of vision and mission, while performance is the measurable outcome expected from an organization. In this respect, there is various literature stresses 
the importance of vision, mission and strategic management on organizational performance, both in for-profit and non-profit areas. Among the earliest are Drucker (1974) and Pearce (1982), who stated the importance of mission statements in driving corporate strategy. Wooldridge (1990) also noted that active involvement of manager in the formulation of strategy, including vision, mission, objective and overall strategic planning could improve for-profit company performance. In the non-profit area, many researchers have acknowledged the significance of mission statement in leading the organization, including Kirk and Nolan (2010), Anheier (2005), Phills (2005) and Bart (1997). Furthermore, organizational performance could be measured by using various indicators such as organizational capacity, organizational effectiveness and shareholder's equity (Wilson, 1992; Campbel, 1993; Rarick and Vitton, 1995).

Not all non-profit organizations recognize the strategic value of developing the right strategy formulation. This issue is also often overlooked by religious-based charity organization, including zakat institution. Consequently, there are very few studies attempt to explore the issue.Johari et al. (2014) reviewed global literature related to zakah during 2003-2013 periods and did not mention anything about papers/researchers related to strategic management of zakah institutions.Vision, mission and strategic planning in non-profit institution often pictured as a part of ethics to stakeholder, corporate governance and Muslim leadership (Beekun, 2006; Sarif; 2015), but there is no attempt to formalize or address the issue in strategic management terms.

With these perspectives, there are three main issues addressed in this study, namely process in formulating vision and mission statement, an approach in implementing strategic planning and impact of strategic management on the performance of zakah organizations different types of zakah organizations in Indonesia (i.e., government, corporate and private based zakah organizations). In order to achieve the objectives, this study employs a mixed method which combines a qualitative research approach with semi-structured interviews with key management personnel of several large zakah organizations in Indonesia and a quantitative approach based on financial data from the organizations. The data obtained were subsequently analyzed by using content analysis, thematic analysis, and ratio analysis. This paper follows Horton et al. (2003) in using organizational capacity as one of the measures of organization's performance.

The structure of this paper is as follow. Section 2 reviews some literature related to the implementation of strategic planning in charitable organizations, especially religious-based organizations. Section 3 discusses the research methods and introduces the data used in the paper. Section 4 presents and analyzes the empirical findings of the study. The last section summarizes the conclusions and highlights recommendations of the study.

\section{LITERATURE REVIEW}

This section discusses several concepts related to strategic planning, such as its definitions and position in strategic management, and implementation of strategic planning for non-profit organizations. It also explains the relationship between strategic planning and organizational performance which becomes the main issue in this study.

\section{Strategic Planning}

In a broader sense, strategic management is defined as the art and science of formulating, implementing and evaluating cross-functional decisions that enable an organization to achieve its objectives. The 
term strategic management is formulation stage in strategic management interchangeably used with strategic (See Figure 1). planning, and used to refer to the

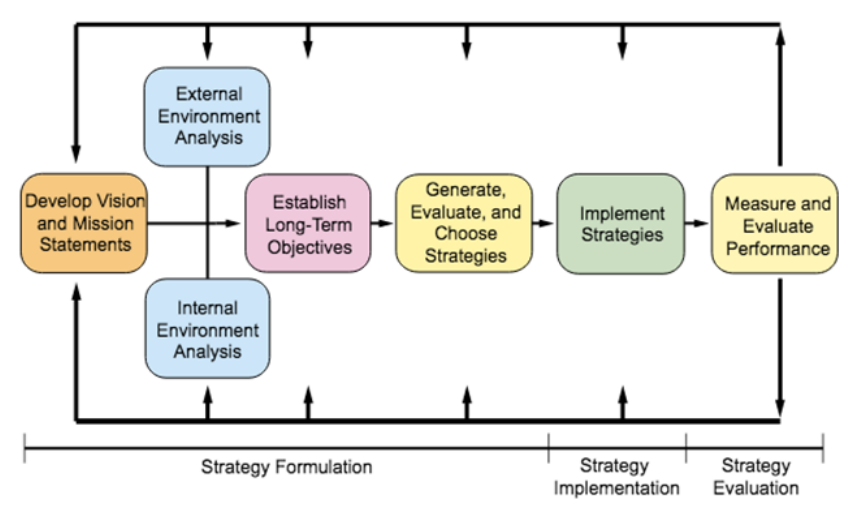

Figure 1. Strategic Management Process Source: David (2011)

In the formulation stage, an organization needs to develop its vision, mission statement, and objective. The mission statement should cover: (1) customers, (2) products or services, (3) markets, (4) technology, (5) concern for survival, growth, and, or profitability, (6) philosophy, (7) self-concept, (8) concern for public image, (9) concern for employees. It is not necessary to include all of the components of the mission statement, as most organization addresses only some that are relevant to their identity (David, 2011).The output will then be used in the implementation stage to generate several strategies that are most suitable for the organization. Lastly, in the evaluation stage, organizations are measuring the standard or target against the organization's result and decide on the corrective action and further improvement.

Since Drucker (1974) introduces vision and mission statement on his seminal work, 'the Handbook of Management,' the application of mission statement in for-profit and nonprofit management has proliferated.In the for-profit sector, the normative vision guiding strategy formulation is already well established, which is to maximize the shareholder's wealth (Porter, 1980; Jensen,
1998). Why is mission becoming more crucial in the non-profit organization? Unlike in the corporate world, the main target of a non-profit organization is not shareholder's wealth; but the achievement of its social purposes and the satisfaction and loyalty of the donor (Oster, 1995). Developing mission statement is an initial step in strategic planning effort and should be considered as the core its performance assessment process (Blackmon, 2008), and the mission should guide to organization's goals, and it is vital in directing the dos and don'ts of the organization (Brown and Iverson, 2004). Hence, strategic planning is equally important for the non-profit, as well as the for-profit organization (Bryson, 1983), the non-profit organization faces increasing demand to perform ideally, which is to set action based on its mission.

In non-profit areas, strategic planning is often not included in the formal process. The rationale behind this idea is that there are not many non-profit organizations adopting the formal strategic planning; instead, they used it as tactical and operational planning tools (Crittenden, Crittenden \& Hunt, 1988; Tober, 1991; Wolch, 1990). Previous literature has found that a lot of non-profit organizations only practice formal strategic 
planning when they are required to submit a plan for funding (Brown \& Covey, 1987; Stone, 1991). Size of a non-profit organization is among the factors affecting the availability of strategic planning in the non-profit organization (Wolch, 1990). The bigger the organization, the more they need coordination and human resources to suffices the need for formal planning. The number of managers recruited from the for-profit company also contributed to the availability of formal planning in the non-profit organization (Young \& Sleeper, 1988). Another factor contributing to the formal planning is the areas of the organization's output; if the organization deals with policy planning, then it is more likely to use strategic planning in its formulation stage (Bryson, 1988).

\section{Relationship between Strategic Planning and Organizational Performance}

The impact of strategic planning and organization performance begins as some author analyzes the empirical evidence of the effects of mission statement on performance outcomes (Bart and Hufper, 2004). Such analysis has been done extensively in the forprofit sector, while the non-profit sector has relatively fewer research (Bart, 1999; Bart and Tabone, 1998; Bart and Hupfer, 2004; Forbes and Seena, 2006). They tried to analyze the impact of mission statement on various aspects of an organization such as performance and strategic planning, and the result is very fragmented. There are various forms of non-profit organizational performance, in which financial ratios and balance scorecards are among the most popular forms (Kaplan, 2001 and Gomes and Liddle2009). Other types of organizational performance are organizational efficiency, organizational capacity, reachability, and sustainability index (Kendall and Knap, 2000). Several findings support the evidence of mission statement's impact on company's strategic planning. As stated in Wilson (1992) and Campbel (1993), clear mission statement could result in a $50 \%$ increase in organizational effectiveness. By using mission statement actively; such that it is not only used for a slogan but to guideemployees in their daily tasks; organizations can obtain business objective (Oghojafor, Olayemi, and Okonji (2011) and significantly increases shareholder's equity and organizational performance (Rarick and Vitton, 1995; Kelly and Harrison 2004; Rhodes and Keogan 2005; Hussein 2007; Blackmon 2008; and Franklin 2011). However, some studies did not find any relationship between formal mission statement with financial performance (Bart and Baetz, 1998; Bart and Hupfer, 2004; Bart and Tabone, 1998; Coats et al., 1991; Pearce and David, 1987). The explanations offered for this inconsistency are the fact that mission's impact on firm's performance is indirect and subtle, therefore will need other intervening variables to understand the link between mission statement and organization's performance (Sheaffer, Landau and Drori, 2008). Later research supports the theory of indirect relationship between mission statement and company's performance.

Macedo (2015) found that organizational commitment is the intervening variable between mission statement and organization's performance.Ekpe (2015) adopted qualitative research and found that an effective mission statement could leverage organization's performance when the mission statement is a starting point of organization's planning process. They later found that, only by improving its mission statement and communicating it well, the mission statement could affect the company's performance.

This paper highlights organizational capacity among several measures of organizational performance to gives a clue on what kind of organizational planning leads to a certain situation of organizational capacity. Capacity is 'a set of attributes that help enable an organization to fulfill its missions' 
(Eisinger, 2002). Thus,organizational capacity is often defined as the ability of an organization to acquire the resources necessary to fulfill its mission (Eisinger 2002; Hall et al. 2003; Horton et al. 2003).

Note that, although often perceived similar, the term organizational capacity is different from organizational capability. The concept of capability refers to processes and custom to set up resources into the right group or level in the organization (Eisenhardt and Martin 2000); while capacity is about the link between resources and mission. There are many concepts related to organizational capacity (Cairns et al. 2005), but in the non-profit, it usually explains on how a non-profit gets to achieve its mission. Sharpe (2006) stated that organizational capacity affects the culture of a company and its operational activity. Indeed, in practice, many large charities such as Charity Navigator use organizational capacity as a measure of performance of charitable organization.

Zakah organization could be categorized as a religious-based charitable donation or charity agency with the main aim to combat poverty. In this respect, total charity obtained (zakah collection) and total charity disbursed (zakah distribution) are some of the capacity dimension that could be emphasized as a measure of zakah performance. It is realistic to use the financial capacity dimension to represents the ability of such an organization to develop and deploy financial resources. It will be different in another type of non-profits, say, a cancer foundation, or in public organization where the mission is not highly related to donation.+There are several studies about strategic planning in non profit organization and in government organization, but there are relatively few studies about strategic planning in zakah organization. When explaining about strategic management in Islamic organization, a seminal work of Beekun (2006) only explain about theoretical steps of strategic management process in
Islamic company, including the development of vision and mission statement. More recently, Johari et al. (2014) reviewed global literature related to zakah during the 20032013 period and did not mention anything about papers/researches related to strategic management of zakah institutions. Wahab (2014) try to review literature on Islamic values and principles within the organization. $\mathrm{He}$ found the implementation of several terms related to Islamic work ethics and Islamic management practice, yet only one theme referring to Strategic Management out of 11 themes of Islamic Management Practices. Meanwhile, Sarif et al. (2015) discuss strategic management from an Islamic perspective with approaches to explaining strategic management on general and strategic management concept and terminology found in Islamic sources. They rarely touched upon discussion linking strategic planning and organizational performance.

\section{METHODS}

As previously explained, zakah is an Islamic institution mainly aimed to eradicate poverty and ensure social justice. The reason d'etre should be reflected not only in the performance of distributing zakah proceeds to the poor and needy but also in strategic planning of zakah organizations. As the topics are rarely explored, this study aims to analyze strategic planning practices of zakah organizations in Indonesia and their impact on the organizational performance.

In achieving the objectives, the study employs a mixed method which combines a qualitative research approach with quantitative research approach. Under the former, which is the main method of the study, semi-structured interviews with key management personnel of several large zakah organizations in Indonesia were conducted. The primary data obtained are analyzed using content analysis and thematic analysis. 
Despite various methods in qualitative data analysis in social sciences research nowadays, thematic analysis is mostly used whenever it is necessary to summarize, interpret and compare the key features (themes) from a large qualitative data set(Braun \& Clarke, 2006). This method has been used in some organizational studies (Bryman \& Burgess, 2002; Cassell \& Symon, 2004; Miller, Dingwall, \& Murphy, 2004). Another method utilized was content analysis, which is useful in interpreting documents and communication materials in order that values, intentions, attitudes and cognitions in management and organizational studies might be analysed(Carley, 1997; Duriau, Reger, \& Pfarrer, 2007; Huff, 1990; Kabanoff \& Holt, 1996; Morphew \& Hartley, 2006). Meanwhile, this paper follows Horton et al. (2003), using organizational capacity as the measure of organization's performance. The proxy for the organizational capacity is the growth of collection and distribution of zakah, which are calculated based on relevant financial data obtained from the organizations.

It is notable that the qualitative data is made into transcript and analyzed using software Nvivo 8. To provide insights into the strategic management practices of zakah organizations in Indonesia; vision statement and mission statement were asked during the interview, and the key manager officer stated some explanation about it as well. They are later asked about the strategic planning, mainly in the design and implementation. The managers are encouraged to talk liberally about where do they get inspiration for the strategic design and do they follow a specific strategic pattern. In presenting the coding results, both the identity numbers of respondents (R1, R2, R3, etc.) and the combination of the respondents' identities and the types of zakah agencies they represent (G1-1, G1-2, C1-1, C2-1, etc.) are utilized. The categories of zakah agencies are government-affiliated zakah agency (G), corporate affiliated zakah agency (C) and Private/ Independent zakah organizations (P).

\section{RESULTS AND DISCUSSIONS}

After the data is coded and categorized accordingly, two main themes are found and analyzed, namely mission statement and process of strategic planning. Afterward, organizational capacity is measured and analyzed accordingly. It is notable that all zakah agencies have formulated its mission statement (vision and mission)and the statement was mostly in line with the standard developed by David (2011). From the strategic planning process, it is found that zakah agency has regular program using 'by design' (budgeted, allocated) process, and irregular program using 'by flow' planning. Organizational capacity in all zakah agency showed positive growth in fund collection and distribution over years albeit the highest capacity is found amongst the non-profit zakah agencies. Below is the explanation on each of the theme and results.

\section{Vision and Mission}

Table 1 summarizes the vision and missions, or mission statements, of the zakah agencies, studied. Few of the management personnel interviewed knew the statements from memory, indicating that the organization does internalize its vision and mission statement to its employee. Accordingly, during the interviews, some of them responded by pointing out the statements directly from the annual reports or website. According to strategic management's theories, vision represents a self-statement of "what do we want to become?"+Mission statements are built by providing foundation to overall company's preferred vision.The analysis shows that all zakah entity's vision provided an answer on the question of 'how do we want to become'; however, a 
distinctive pattern between three types of zakah agency is also analyzed.

Table 1. Vision and Missions of Zakah Organizations

\begin{tabular}{|c|c|c|}
\hline Organization & Vision & Mission \\
\hline G1 & $\begin{array}{l}\text { Becoming excellent and } \\
\text { trustworthy management of } \\
\text { zakah, infaq, and sadaqah. }\end{array}$ & $\begin{array}{l}\text { Realizing optimal management of zakah, infaq, and sadaqah } \\
\text { which is trustworthy, professional, transparent, accountable and } \\
\text { independent to help create a pious, prosperous and powerful } \\
\text { society. }\end{array}$ \\
\hline G2 & $\begin{array}{l}\text { To be a national center of } \\
\text { zakah that is trustworthy, } \\
\text { transparent and professional. }\end{array}$ & $\begin{array}{l}\text { (i) To increase people's awareness about paying zakah through } \\
\text { zakah organizations as well as to direct and guide society to } \\
\text { establish social welfare and justice; (ii) To be the coordinator } \\
\text { of all existing BAZ } \text { and LAZ }^{\mathrm{b}} \text { through effective and targeted } \\
\text { synergy; (iii) To be the national data centre, to cover all data of } \\
\text { BAZ/LAZ, zakah collection data from BAZ/LAZ, data of } \\
\text { zakah utilization, including national data of muzakki and } \\
\text { mustahik; (iv) To be the centre of development and mentoring } \\
\text { for national human resources of zakah. }\end{array}$ \\
\hline $\mathrm{C} 1$ & $\begin{array}{l}\text { Becoming the engine of } \\
\text { society's economic } \\
\text { independency to create } \\
\text { communities with strong } \\
\text { character, growing and } \\
\text { caring. }\end{array}$ & $\begin{array}{l}\text { (i) Implementing comprehensive and integrated programs on } \\
\text { economic and social empowerment and (ii) Establishing and } \\
\text { developing the network of empowerment. }\end{array}$ \\
\hline $\mathrm{C} 2$ & $\begin{array}{l}\text { Becoming a prominent zakah, } \\
\text { infaq and sadaqah } \\
\text { management that is } \\
\text { trustworthy, professional and } \\
\text { compliant with Islamic law } \\
\text { (shariah). }\end{array}$ & $\begin{array}{l}\text { (i) Optimize collection and distribution of zakah, infaq and } \\
\text { sadaqah within the organizations and in society in general; (ii) } \\
\text { Improve the utilization of zakah funds properly and effectively; } \\
\text { (iii) Conduct all activities based on the principle of Good } \\
\text { Corporate Governance. }\end{array}$ \\
\hline P1 & $\begin{array}{l}\text { To implement an empowered } \\
\text { community that relies on } \\
\text { local resources through a fair } \\
\text { system. }\end{array}$ & $\begin{array}{l}\text { (i) To develop the value of humanity and independence; (ii) To } \\
\text { enhance the society's charitable giving and resources support } \\
\text { for empowerment; (iii) To stimulate the synergy of programs } \\
\text { and empowerment of the organization's network in the global } \\
\text { community; (iv) To develop and utilize people's assets through } \\
\text { a fair economy; (v) To develop zakah as an alternative method } \\
\text { of poverty alleviation. }\end{array}$ \\
\hline P2 & $\begin{array}{ll}\text { Becoming an } & \text { international } \\
\text { philanthropic } & \text { organization } \\
\text { based on } & \text { professional } \\
\text { empowerment. } & \end{array}$ & $\begin{array}{l}\text { (i) Actively involved in building international philanthropic } \\
\text { networks; (ii) Facilitating society's empowerment and (iii) } \\
\text { Optimizing all resource aspects through excellent human } \\
\text { resources. }\end{array}$ \\
\hline P3 & $\begin{array}{l}\text { To be the most reliable } \\
\text { organization for developing } \\
\text { independency. }\end{array}$ & $\begin{array}{l}\text { (i) To efficiently make use of programs such as rescue, } \\
\text { rehabilitation, and empowerment to develop self-sufficiency; } \\
\text { (ii) To establish partnerships with both national and } \\
\text { international communities, corporations, governments and } \\
\text { NGOs; (iii) To provide underprivileged societies (beneficiaries) } \\
\text { with information, education and advocacy. }\end{array}$ \\
\hline
\end{tabular}

Source: Annual Reports, website and interview results; Note: ${ }^{\mathrm{a}}$ Refers to Government Zakah Organization, ${ }^{\mathrm{b}}$ Refers to Non-Government Zakah Organization, ${ }^{\mathrm{c}}$ For anonymity, the organization's name in the text is replaced with the general term "the organization", d Refers to Non-Government Organizations; After 2017, some of the mission statements are changed or adjusted by the organizations.

Into the main analysis, using keyword-in-context (KWIC) method of content analysis, several 'key words' are identified in the mission statements. As portrayed in the tag-cloud illustration (Figure 2), they include the words 'professional', 'trustable/trustworthy,' 'independency,' 'empowerment', 'society,' 'human', 'people', 
and 'accountable'. These words are presumably the most 'common themes', which provide the foundations of what the institutions want to be and achieve with their overall programs and activities.A closer examination of the mission statements indicates that the common topics can be framed within two main themes. General terms, verbs and prepositions such as 'management', 'through', 'becoming' and 'involved in' are excluded from the analysis.

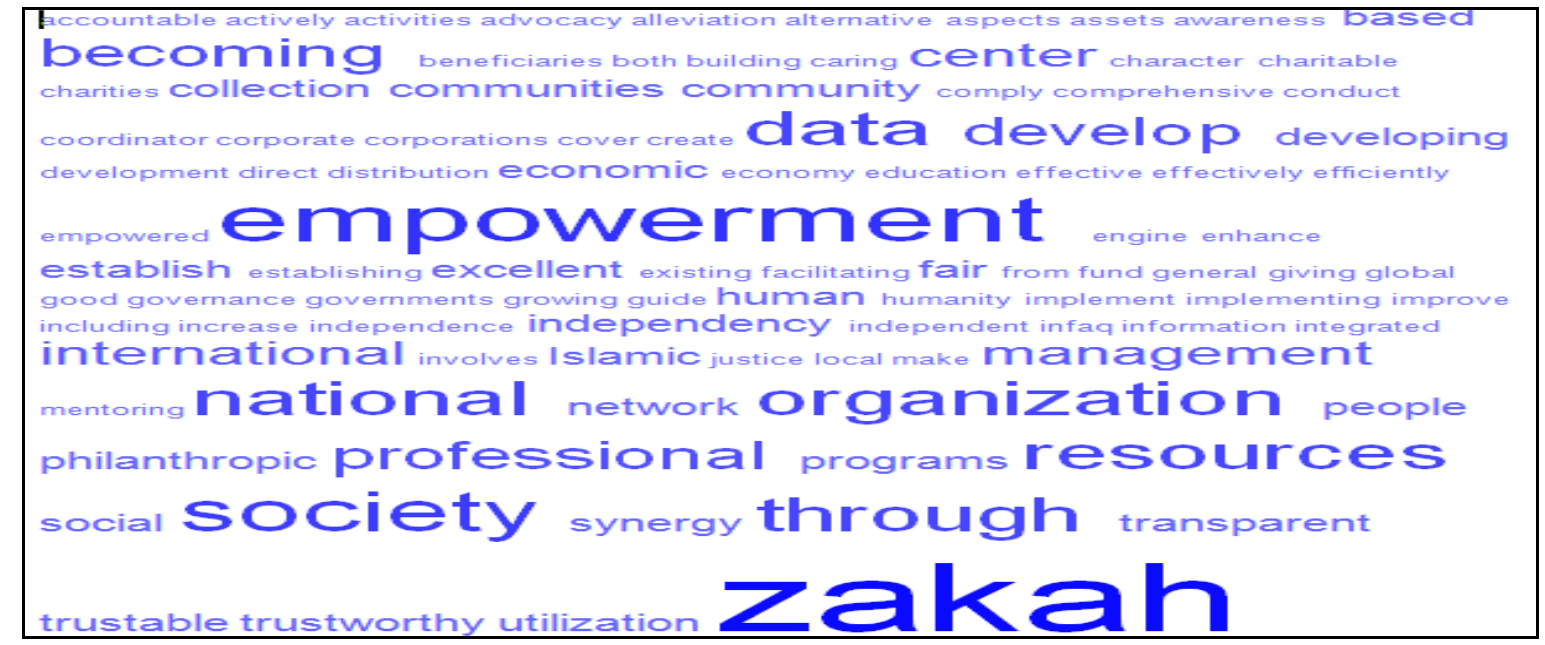

Figure 2. Key Words of the Mission Statements Source: Data analysis with NVIVO-9

As summarized in Table 2, the organizations seem to focus on achieving either particular organizational characteristics or particular organizational outcomes. The themes lead to a general understanding that different types of zakah agencies have different perspectives and 'idealized views' of their organizations. All zakah agencies mention its primary task and its value (selfconcept). Government based type of zakah agency follows the standardized pattern of mentioning identity in its vision such as mentioning 'zakah' and point out its duty of managing zakah. Meanwhile, despite the main role as a zakah agency, none of the private zakah agency ever mentioning the word 'zakah' or 'infaq' or 'shadaqah' on its vision. By not mentioning the word 'zakah', it appears that most of the private zakah agency aims to disentangle from customer's perception of zakah fund as their only resource for funding. After all, there are many donation forms other than zakah.

Table 2. Focuses of Vision/Missions of Zakah Organization

\begin{tabular}{|l|l|}
\hline Interview Question & $\begin{array}{l}\text { What is the vision and missions of your organization? What are they focused } \\
\text { on? }\end{array}$ \\
\hline Focused coding & Subthemes/Remarks \\
\hline 1 & Focus on characteristics of organization \\
\hline 2 & Focus on managerial activities and related outcomes to be achieved \\
\hline Concluding theme & $\begin{array}{l}\text { Different types of zakah organizations have different focuses regarding what } \\
\text { they want to be and achieve with their program/activities }\end{array}$ \\
\hline
\end{tabular}

Source: Data analysis

Furthermore, by employing the word frequency method of content analysis, it was possible to identify several organizational characteristics extensively mentioned in the 
statements (see Table 3). All zakah agencies did mention about its self-concept as a trusted and accountable organization. The most widely cited word is 'trustable/trustworthy/reliable', which was mentioned five times and constituted $1.8 \%$ of the total words in the mission statements. The words 'professional' and 'independency/independent' were each found in four locations $(1.44 \%)$. These characteristics, which could be seen as 'selfconcept' that the institutions wanted to achieve, were recognized by all organizations regardless of their type. Two other widely cited words, namely 'international/global' and 'transparent/accountable', were mentioned by different types of organization. In particular, the former was only cited by the private zakah organizations while the other was mentioned by almost all institutions. One based government agency aimed to operate at national level and most of the private zakah agency targeted international exposure and networking. Table 4 lists activities and targets/outcomes frequently mentioned in the statements. Corporate affiliated zakah agency and private zakah agency mention its target beneficiaries(zakah receiver) but government zakah agency did not. The main managerial activities, such as collection and distribution/utilization of zakah, were cited by all agencies in at least 17 locations (5.04\%). Similarly, the words 'society(ies)', 'community(ies)', 'people' and 'human', which were the main 'targets' of the institutions, were mentioned in 15 locations $(4.69 \%)$.

Table 3. Focused Coding 1 for the Vision/Mission Statements

\begin{tabular}{|l|l|}
\hline Subtheme & Focus on organization's characteristics \\
\hline Interview with & Remarks \\
\hline G1, C2; G1, G2; P3 & Trustable; trustworthy; reliable $(1.8 \%)$ \\
\hline G1, G2, C2, P2 & Professional $(1.44 \%)$ \\
\hline C1, P3; G1, P1 & Independency; independent $(1.44 \%)$ \\
\hline P1, P2, P3 & International, global $(1.44 \%)$ \\
\hline $\mathrm{G} 1, \mathrm{G} 2$ & Transparent; accountable $(1.08 \%)$ \\
\hline
\end{tabular}

All of the zakah agency addresses its customer and states that society or community is their customer, with only government zakah agency mention clearly about its customer (muzakki), its recipient (mustahik) and its duty to serve other zakah agency (BAZ and LAZ). National government related zakah agencies (BAZNAS) also supervises other government zakah agency (BAZNAS Province, BAZNAS regency/city), they are categorized as government affiliated zakah agency (BAZ), while LAZ consists of corporate affiliated zakah agency and independent zakah agency. Interestingly, when all of the zakah organization mentioned their product and services; the type of product and services mentioned are quite varied.

Government based zakah agency mentioned zakah along with infaq and shadaqah as their main services, corporate based agency mentioned zakah along with other general empowerment program; and private zakah agency mentioned most of their empowerment and advocacy program, did not even mention zakah on its mission statement. Stronger outcomes such as 'empowerment' were emphasized only by the private zakah agencies. Meanwhile, more 'philosophical' terminologies such as 'prosperous', 'pious', 'welfare' and 'poverty alleviation' were emphasized only by the government agencies. These orientations 
could potentially influence the management's direction and practices.

Findings from this paper imply that all types of zakah agency have a respectable mission statement, with private zakah agency's mission statement being the most sophisticated with regards of targeting activities which are more extensive than 'normal' charity works.Private zakah agency did not mention zakah as its primary task, did not emphasize on its main duties of collecting and distributing zakah; but instead refer to enhancing empowerment and building independency, and aim to serve communities at international level.

There are at least two possible explanations for this finding. Firstly, private zakah agency has its human resources 'borrowed' or was previously working on forprofit organization (Young and Sleeper, 1988).

Previous research has stated that managers that were once from the for-profit organization are more familiar with strategic planning stages and implementation, thus more likely to implement the strategic planning process and adhere the mission statement in the non-profit. However, this assumption needs further proof to identify whether private zakah agency has its human resources from for-profit pool of talent.

Table 4. Focused Coding 2 for the Vision/Mission Statements

\begin{tabular}{|l|l|}
\hline Subtheme & Focus on activities and targets/outcomes to be achieved \\
\hline Interview with. & Remarks \\
\hline G2, C2, G1, P1, C1; P3; G2; P2 & $\begin{array}{l}\text { Collection, utilization/distribution programs (economic, social, education, etc.); } \\
\text { advocacy; increase awareness (about paying zakah), mentoring; facilitating } \\
(5.04 \%)\end{array}$ \\
\hline $\mathrm{G} 1, \mathrm{G} 2, \mathrm{C} 1, \mathrm{C} 2, \mathrm{NI}, \mathrm{P} 2, \mathrm{P} 3$ & Society(ies), community(ies), people, human (4.69\%) \\
\hline $\mathrm{C} 1, \mathrm{P} 1, \mathrm{P} 2, \mathrm{P} 3$ & Empowerment/empowered (2.53\%) \\
\hline $\mathrm{G} 1 ; \mathrm{G} 2 ; \mathrm{P} 1$ & Prosperous; welfare; poverty alleviation $(1.08 \%)$ \\
\hline $\mathrm{P} 1, \mathrm{G} 2$ & Fair (system, economy), justice (1.08\%) \\
\hline
\end{tabular}

Source: Data analysis

Secondly, private zakah agencies have more varied and dynamic sources of retail funding, thus more likely to appeal for bigger pressure to satisfy their stakeholder. For example, as the non-profit has larger stakeholders' based, values such as accountability and professionalism are emphasized in the mission statement (Kasri, 2018). Therefore they are more likely to develop elaborate planning and strategically oriented approach to their marketing, most likely they will learn from international nonprofit organizations.

\section{Strategic Planning}

Strategic planning involves the process of generating and subsequently choosing particular strategies and programs to pursue. According to the interviewees, the strategic planning process could be generalized into two themes, namely "by-design" and "byflow" strategies (Table 5). The former refers to the strategy/program formulation focusing on the planning based on internal processes within the organization. Meanwhile, the latter indicates the planning process that is more responsive to external and environmental forces. The information gathered led to an understanding that the majority relies on the by-design process albeit most of them used both approaches in generating their strategies. However, the latter is maintained by some agencies due to the nature of the zakah institution which must be responsive to the urgent needs of society. 
Table 5. Strategy and Program Planning

\begin{tabular}{|l|l|}
\hline Interview Question & How do you generate and plan the policies and program ideas? \\
\hline Focused Coding & Subthemes/Remarks \\
\hline 1 & By-design (more responsive to internal factors/process) \\
\hline Concluding Theme & $\begin{array}{l}\text { By-flow (more responsive to external factors) } \\
\text { Different organizations have different approaches for generating policies and } \\
\text { frogram ideas, which could be classified into (i) by-design approach and (ii) by- } \\
\text { flow approach. Most of them, however, rely on the former. }\end{array}$ \\
\hline
\end{tabular}

Source: Data analysis

Table 6. Focused Coding 1 for the Strategy and Program Planning

\begin{tabular}{|l|l|}
\hline Subtheme & Program generation with by-design approach \\
\hline Interview with & Remarks \\
\hline R9 (C1-1), R11 (C2-1), R21 (P2-1), & Adopting and modifying similar programs of other organizations \\
R22 (P3-1) & \\
\hline R9 (C1-1), R21 (P2-1), R4 (G2-2) & Improvement of the current programs \\
\hline $\begin{array}{l}\text { R7 (G2-5), R14 (P1-1), R21 (P2-1), } \\
\text { R22 (P3-1), R11 (C1-1) }\end{array}$ & Poverty and social mapping \\
\hline R21 (P2-1) & $\begin{array}{l}\text { Inspiration/analogies from religious stories, particularly, stories of the Prophets } \\
\text { (sirah nabawiyah) }\end{array}$ \\
\hline
\end{tabular}

Source: Data analysis

Table 6 provides the responses and insights of respondents who believed that their organizations had practiced the "bydesign" strategy. There are at least four processes or 'methods' used under this strategy, as elaborated below:

\section{a) Adoption/modifications of similar programs}

Adaptation and/or modification of successful programs implemented by other institutions with similar missions were the methods used by almost all of the agencies to generate the programs. This was emphasized by R11, the General Manager of $\mathrm{C} 2$, who stated that, "Talking about programs...we have almost the same programs as other zakah organizations. We have education, healthcare, economic and socio-religious programs..." In some cases, the inspiration might come from successful programs initially implemented by foreign institutions. R22, the Deputy CEO of P3, mentioned that, "...now we have a village-based empowerment program. We take an example from Japan: one-village one-product program..." Meanwhile, R9, Executive Director of $\mathrm{C} 1$, admitted that its Islamic microfinance program was a modification of the Grameen Bank concept. ${ }^{1}$

\section{b) Improvement of existing programs}

Evaluations and improvements carried out by the organizations were also mentioned as one of the mechanisms used to create a new and better program. For example, R9 stated that the IT system was implemented after he felt that there was a need to improve and "tidy

\footnotetext{
${ }^{1}$ It is mentioned that, "Yes, similar [to the Grameen Bank concept]. Indeed, we adopted some of the ideas from there. However, Grameen was only intended for women. This has weaknesses, because it is said to have negative impacts on families...In our program, the management must be done together [by both husband and wife]. This is so because responsibility to earn a living relies on the husband. So, we take the positive [lessons] from Grameen..."
} 
up" the previous administration system due to the increased amount of paperwork related to higher zakah collections. Others mentioned that evaluation of existing programs based on the feedback of zakah payers, mostly obtained from surveys, was the main consideration to improve the existing program. While in general this practice is quite natural for most of the formal organizations, especially corporations, this was not the case for most zakah agencies in Indonesia.

\section{c) Poverty and social mapping}

Although the idea that links zakah with poverty alleviation is relatively new in Indonesia, the interview results suggest that poverty and social mapping have been important drivers of the programs implemented by the agencies. As explained by R7 (G2-5), "In making policies, we firstly try to map [them] based on the poverty map that we know...After that, we create the program". Similarly, R14 (P1-1) mentioned that "...it [the program planning] is started with poverty mapping..." Furthermore, the mapping was usually done by utilizing various types of poverty data, such as official poverty data, poverty maps created by other organizations and recommendations from third parties. These facts were also acknowledged by R22 (P3-1) and R11 (C2-1) during the interviews.

\section{d) Inspiration from religious stories}

One zakah agency contended that religious 'mindsets' and historical events play important roles in shaping their programs. In his narrative about the inspiration for an integrated community development program successfully conducted by his organization, R21 explained that they were inspired by the migration (Hijrah) of the Prophet Muhammad
(PBUH) from Makkah to Madinah. ${ }^{2}$ This 'inspiration' is unique, in the sense that it emphasizes the stories of the Prophet (PBUH) and the Islamic values inherently held by a zakah agency; something that makes it different from other types of voluntary institutions. In reality, it seems that few have attempted to 'internalize' and use Islamic narratives in the management process. Nevertheless, as also suggested from the other interviews, Islamic values such as trust and hard work have a central place in the organizational culture and seem to correlate with the organizations' "professionalism" orientation.

Proceeding to the second mechanism, Table 7 summarizes two major processes of program planning under the "by-flow" strategy. The explanations are as follows.

\section{a) Responding to the needs of mustahik}

This was the most extensive strategy used under the "by-flow" program design. As stated by R8, the Program Manager of G2, "...in essence, we created our programs

2 It is mentioned that,"We were inspired by the migration (Hijrah) of the Prophet Muhammad (PBUH) from Makkah to Madinah. When he migrated, what he firstly built was the [people's] mindset. If the mindset has changed, then the Madinah people could be directed towards Islamic belief (aqidah). We were the same. When we came to a village, we changed the people's mindsets... behaviors: that you [the villagers] are capable, have potentials...That's what we wanted to build. Second, after the mindset of the Madinah people [has changed into] 'Islam', the Prophet (PBUH) built a mosque. He prepared the mosque not only for praying but also for the Islamic society's activities, [giving] motivation, education, etc. We built the socalled Bina Mandiri Hall (Balai Bina Mandiri). It could be used for meeting place, for training purpose, etc. The third stage, when the mosque had been built, then he built a marketplace. The market here refers to the real market that could improve the economic growth in Madinah. Similarly, we prepared the marketplace [for the mustahik]..." 
based on mustahik needs. Otherwise, why would we make the programs? That is the standard logic built in this organization..." Moreover, according to R22 (P3-1), "So, in many aspects, our programs are very customized...they are always based on the need and interest of the society". It is also notable that this style was particularly preferred in administering disaster relief programs, which require a relatively customized program design.

Table 7. Focused Coding 2 for the Strategy and Program Planning

\begin{tabular}{|l|l|}
\hline Subtheme & Program generation with by-flow approach \\
\hline Interview with & Remarks \\
\hline $\mathrm{R} 7(\mathrm{G} 2-5), \mathrm{R} 8(\mathrm{G} 2-6), \mathrm{R} 11$ (C2-1), & Responding to the need (request) of mustahik, which is sometimes triggered by \\
$\mathrm{R} 14(\mathrm{P} 1-1), \mathrm{R} 21(\mathrm{P} 2-1), \mathrm{R} 22(\mathrm{P} 3-1)$ & 'external' events such as natural disasters \\
\hline $\mathrm{R} 11(\mathrm{C} 2-1), \mathrm{R} 22(\mathrm{P} 3-1)$ & Input from muzakki and other external parties \\
\hline
\end{tabular}

\section{b) Input from muzakki (donors) and other external parties}

Although not very common, another method found under this strategy was planning based on input from external parties. An example was given by R22 (P3-1) from the non-profit agency, "Quite some time ago, there was a research institution that told us 'Do you see that village? Pity the child there...' 'Why?' 'None of the school children have shoes'. So, sometimes this kind of thing encourages us to make the [free shoes] program". Another example was "the motivation and breaking the fast (iftar) program for prisoners", a popular program implemented by many large zakah agencies. The program was created after a former (political) prisoner - who was coincidently a muzakki of that agency brought the idea to one of the management personnel.

Overall, the findings suggest that zakah agencies in Indonesia follow two categories of planning patterns, namely 'by design' and 'by flow' approaches. Planning by design indicates that the organization has fixed or long-term programs planned before the implementation phase, which is practiced by all types of the zakah organizations. The idea could come from (i) adoption/modifications of similar programs, (ii) improvement for existing program, (iii) Poverty or social mapping and (iv) values inspired from Prophet's success stories of developing empowered society. The combination of elements of the by design planning constitutes of somewhat a formal planning (Bryson, 1988) which includes modification and improvement of strategy, internal and external audit by doing demand mapping, as well as instilling values and philosophy into its organizational culture through stories, in this case, is religious based stories. It is also notable that, to gain approval for the policies/programs, all agencies have a standard procedure. ${ }^{3}$

In contrast, the planning by flow approach, does not indicate that the organization is run with a liberal procedure or without a standard of operating procedure, but to imply that its planning is highly adaptable to suit the need of its main

3 Based on the interviews, it is revealed that the procedure generally includes the following mechanisms: (i) discuss the ideas generated in internal meetings; (ii) draft an annual program planning; (iii) bring them to the Advisory Board for approval and (iv) implement the programs, once the approval is received. Furthermore, to guide the program implementation, most organizations have some kind of Standard Operating Procedures (SOPs) for important management procedures. The SOPs were expected to support employees in performing their tasks properly. They were also an inherent part of organizations wishing to acquire international management quality certifications. 
stakeholders, that is the beneficiaries (mustahik). Indeed, all types of zakah agency mentioned that they listened to the need of their mustahik. However, it is interesting to note that the zakah payers could also indicate their preference concerning the zakah that they paid through the corporate and nonprofit zakah agencies. This finding indicates that the agencies also concern about preference of the muzakki and aim to maintain a trust-commitment and long-term relationship, which is often termed as 'relationship marketing' (Sargaent, 1999; Sargaent and Lee, 2004; Kasri 2013) in marketing management of voluntary sector.

The results also imply that, to assume that one strategy fit for all in the non-profit context is rather misleading, because even in the for-profit organization, the plan should be flexible enough to allow alteration and improvement. Especially in the zakah areas where combating poverty is the common spirit, the program is understandably depends on the availability of the ashnaf(obligatory recipient of zakah). There are eight categories of ashnaf: the fuqara (poor), al masakin (needy), amil (zakah collector), muallaf(new muslim), riqab (captives/slave), gharimin (those in debt), fiisabilillah(those who fight in the name of Allah) and ibnu sabiil (wayfarer). Except for the first two groups of recipients (i.e. poor and needy), scholars agree that the categories are not in order of priorities (Kahf, 1989); hence it is varied highly depends on the needs of ashnaf in certain areas. Some of the zakah are meant to serve the poor and needy, some are to build schooling infrastructure and some are directed to build water reservoir and watering system for agriculture (Gumelar,2018). It is likely for the non-profit organization to have 'regular' beneficiaries such as the needy and the poor or any targeted ashnafthe organization wants to serve, but they also havenew programs that are at least flexible enough to cater the needs of the new fragile communities such as survivors of natural disaster. After all, Indonesia is one of the countries with highest number of natural disasters.

To account for the empirical differences in (i) by design and (ii) by flow design, one should understand the demand characteristics of one area and how each zakah agency develop its program to cater the needs of their beneficiaries. When the need for beneficiaries is diverse and fragmented, a dedicated non profit does not have to set certain objectives and goals (Bryson, 1988). The by flow design may seems difficult to assess, but what must be accounted during performance measurement for the 'by flow' approach is that the result is not to be measured by any predefined standard, because the target are changing or tailored based on mustahik (beneficiaries) needs. Popular tool in strategic management such as Balanced Score Card and efficiency measures such as data envelopment analysis are preferable for both approaches.

Another finding worth mentioned is that in the by design approach, the non-profit should have the ability to conduct poverty or social mapping in most of the zakah agency as showed by the most of the zakah institution on the sample. This is a beneficial stage as important as SWOT stage in strategic planning. By developing the poverty or social mapping, non-profit has already empirical data in linking the environment to strategy content and implementation (Blackmon, 2008).

\section{Organizational Capacity}

Revenue and distribution of zakah proceeds are indicated by the growth rates of the funds, as it reflects the organizational capacities in achieving its vision and mission. Collection and distribution of zakah in the last three years were measured among all of the zakah agency samples to get the growth rate of collection and distribution. As shown in table 8 , the result indicates that private zakah agency has collected and distributed highest 
fund, double the mean amount of funds collected by the government agencies and triple the amount raised by the corporate agencies.

Table 8. Organization Capacity Data based on Types of Zakah Agency in Indonesia

\begin{tabular}{|c|c|c|c|c|c|}
\hline Variable & Obs. & Mean & Std. Dev. & Min & $\operatorname{Max}$ \\
\hline \multicolumn{6}{|c|}{ Type $=1$ (government $z$ akah organization) } \\
\hline $\begin{array}{rll}\text { Total } & \text { revenue } \\
\text { million) }\end{array}$ & 6 & $48,646.88$ & $18,216.75$ & $26,377.11$ & $75,658.62$ \\
\hline \begin{tabular}{|rl} 
Total distribution & (IDR \\
million)
\end{tabular} & 6 & $35,040.26$ & $11,963.70$ & $17,620.23$ & $53,081.87$ \\
\hline Growth of total revenue & 4 & 0.2565076 & 0.0548198 & 0.2082424 & 0.3333545 \\
\hline Growth of total distribution & 4 & 0.4176596 & 0.1929414 & 0.2910556 & 0.704738 \\
\hline \multicolumn{6}{|c|}{ Type $=2$ (corporate $z a k a h$ organization) } \\
\hline \begin{tabular}{|rrr}
$\begin{array}{r}\text { Total } \\
\text { million) }\end{array}$ & revenue \\
\end{tabular} & 6 & $28,510.61$ & $15,180.40$ & $11,518.75$ & $52,130.25$ \\
\hline \begin{tabular}{|rrr}
$\begin{array}{r}\text { Total distribution } \\
\text { million) }\end{array}$ & (IDR \\
\end{tabular} & 6 & $21,702.53$ & $12,479.16$ & $8,425.65$ & $41,919.15$ \\
\hline Growth of total revenue & 4 & 0.8603499 & 1.784044 & -0.1885709 & 3.525684 \\
\hline Growth of total distribution & 4 & 0.9223124 & 1.294984 & 0.071439 & 2.848854 \\
\hline \multicolumn{6}{|c|}{ Type $=3$ (privatezakah organization) } \\
\hline \begin{tabular}{|rcr} 
Total & revenue \\
million) & & \\
\end{tabular} & 8 & $118,420.30$ & $57,961.53$ & $22,528.76$ & $191,706.60$ \\
\hline \begin{tabular}{|rl} 
Total distribution & (IDR \\
million)
\end{tabular} & 8 & $113,214.80$ & $60,852.99$ & $5,179.29$ & $172,220.10$ \\
\hline Growth of total revenue & 5 & 0.5614448 & 1.076611 & -0.0252147 & 2.477559 \\
\hline Growth of total distribution & 5 & 2.406975 & 5.101764 & 0.0567847 & 11.5317 \\
\hline
\end{tabular}

Source: Data Analysis

In total revenue growth, the corporate agencies recorded the highest growth rate of $86.03 \%$ during the period, even if it is still half the revenue of private zakah agency. This is followed by the non-profit and government zakah organizations. In distributing the fund, the private zakah agency shows a consistent superior growth even if the corporate agency is showing the higher growth rate.The general trend is a gradual increase in both total collection and distribution, and even if private zakah agency leads in nominal, corporate affiliated zakah agency has the highest growth rates. These results suggest that the corporate zakah agency has the highest revenue capacity, while the non-profit agency has the highest distribution capacity compared to the others.

\section{Linking Strategic Planning to Organizational Capacity}

From explanations in the previous sections, some interesting findings could be highlighted. The strategic planning process could be generalized into two themes namely "by-design" and "by-flow" strategies and both approach lead to some notable differences in the strategic management practices amongst different types of zakah organizations, albeit they are not very strong. It is also known from the qualitative data we found that zakah agency is constantly improving its strategic planning by mimicking from international and national benchmark. Siddique and Mohamed (2007) stated that even in the case of Malaysian government based zakah agency, constant reform and benchmarking to international standard were part of the planning. 
In Indonesia, most of the zakah agencies were previously run without formal strategic planning. Small and scattered organization, zakah caretaker were mosque administrator that contribute zakah voluntary payment by mosque visitor to the needy and poor in the areas. There is no doubt that the emerging of national organization such as DompetDhuafa and Rumah Zakat, along with the increasing awareness of Islam and Islamic economics (including Islamic banking and research on Islamic economics) during the 1990-2000 period is the first attempt to bring zakah into mainstream charity. In 2011, the government announced the BadanAmil Zakat Nasional or BAZNAS (National Board of Zakah) to become the main collector and the supervisory body for all other private zakah institution along with the Zakah Act No 23/2011 as the regulatory bases for BAZNAS.

According to strategic management theories, factors that affecting formal planning in the non profit includes the size of the organization, funder requirement, characteristics of board and manager's exposure on formal planning (Stone, 1999). Hence, as those early zakah organization grew, they became bigger and began to recruit professionals from the for-profit areas, 'importing' for-profit knowledge and professionalism into the charity world. The results are what we saw from the data in this paper, nowadays, every formal zakat organization in Indonesia seems to adopt formal strategic planning.

The study also found that all zakah agencies have a dedicated mission statement, with private zakah agency being the most sophisticated. There are no distinctive design attributed to a certain types of zakah agency and mission statement. Therefore all zakah company seems to share both by design and by flow planning with regular program is designed and budgeted and irregular program is planning by flow to adapt to emergency situation which often occurred in prone disaster areas in Indonesia. Nevertheless, in implementing the by flow approach, it is notable that at that time only the nongovernment (i.e. corporate and non-profit) zakah organizations show concern about preference of zakah payers.

Based on the overall findings above, we seek to analyze whether certain strategic design and certain types of zakah organizations affect organizational performance. It is evident from the findings that the corporate zakah agency has the highest revenue capacity, while the nonprofit agency has the highest distribution capacity compared to the others. The highest revenue capacity and distribution capacity are associated with implementing both the by design and the by flow approaches with the most 'comprehensive' tools and strategies in their strategic planning. The superior result shown by the corporate affiliated zakah agency are presumably attributed to the readily available resources of revenues, such as parent company's profit and parent company's employee donation. It might also be related to the professional management practices that it adapts from its for-profit parents. Furthermore, the excellent distribution capacity shown by the non-profit agency might be a reflection of trying their best to maintain long-term relationship based on trust and commitment with the donors or zakah payers, something which might not be a priority for the others which 'luckily' have stronger based of donors based on internal affiliation.

As excellent growth rate of collection and distribution showed by non profit and corporate affiliated zakah agency were in line and positively related with their mission statement, the findings of the study are therefore consistent with the results of previous studies (see,among others, Rarick and Vitton, 1995; Kelly and Harrison 2004; Rhodes and Keogan 2005; Hussein 2007; Blackmon 2008; and Franklin 2011). However, the exact relationship between mission statement and performance in zakah company needs to be researched further. 


\section{CONCLUSIONS}

The study found several interesting findings that presumably attributed to the different type of zakah agency in Indonesia. First, in their mission, zakah organizations seem to have different idealized views and focus on achieving either particular organizational characteristics or organizational targets/outcomes. Second, the strategic planning processes tend to follow the "by-design" and the "by-flow" strategies which are implemented in all zakah agency, regardless of its type. However, it is notable that at that time only the non-government zakah agencies were flexible enough to run programs based on the recommendation of their donors. Third, it is found that corporate zakat agency has the highest collection capacity, while the private zakah agency has the highest distributional capacity.

Based on the findings, it is suggested that the organizations should focus on their targets/outcomes and properly design their programs. It is also argued that all zakah agency has been formulating a sound mission statement and it is reflected well in the organizational capacity. This implies that there is a positive relationship between strategic planning and organizational performance. However, to enhance the effectiveness of strategic planning to achieve the institutional objectives (and perhaps go beyond the target), it is also important to allow some program flexibility based on trust and commitment with the main stakeholders (particularly donors). The findings are expected to provide more insights and enrich literature regarding strategic management practices of zakah institutions in Muslim countries.

\section{REFERENCES}

Al Qardawi, Y. (2000). Fiqh Al Zakah: A Comparative Study of Zakah, Regulations, and Philosophy in the
Light of Quran and Sunnah. Jeddah: King Abdulaziz University.

Andreasen, A., \&Kotler, P. (2003). Strategic marketing for non-profit organizations. New Jersey: Prentice Hall.

Anheier, H. K. (2005). Nonprofit organizations: Theory, management, policy. Oxon: Routledge.

Armstrong, J., \& Overton, T. (1977).Estimating non-response bias in mail surveys.Journal of Marketing Research, 14, August.

Baetz, M. C., \& Bart, C. K. (1996).Developing mission statements which work. Long Range Planning, 29(4).

Bakar, M. H. A., \&Abdghani, A. H. (2011).Towards achieving the quality of life in the management of zakat distribution to the rightful recipients (the poor and needy).International Journal of Business and Social Science, 2(4).

Bart, C., \&Hupfer, M. (2004).Mission statements in Canadians hospitals.Journal of Health Organisation and Management, 18(2), $92 \mathrm{e} 110$.

Bartkus, B., \& Glassman, M. (2008). Do firms practice what they preach? The relationship between mission statements and stakeholder management.Journal of Business Ethics, 83(2), 207e216.

Beekun, R. I. (2006). Strategic planning and implementation for Islamic organizations.IIIT.

Benkhoff, B. (1997). Ignoring commitment is costly: new approaches establish the missing link between commitment and performance. Human Relations, 50(6), $701 \mathrm{e} 726$.

Braun, V., \& Clarke, V. (2014). What can "thematic analysis" offer health and wellbeing researchers?.International journal of qualitative studies on health and well-being, 9 . 
Bryce, H. (1992). Financial and strategic management for nonprofit organizations. Englewood Cliffs, NJ: Prentice Hall.

Bryman, A., \& Burgess, B. (Eds.). (2002). Analyzing qualitative data. Routledge.

Bryson, J. M. (1995). Strategic planning for public and nonprofit organizations. San Francisco: JosseyBass.

Campbell A. 1993. The Power of Mission: Aligning Strategy and Culture. Planning Review (Special Issue) 20(5): 10-12

Campbell, A., \&Yeung, S. (1991). Creating a sense of mission. Long Range Planning, 24(4), 10e20.

Carley, K. M. (1997). Extracting team mental models through textual analysis. Journal of Organizational Behavior, 533-558.

Cassell, C., \&Symon, G. (2006).Taking qualitative methods in organization and management research seriously. Qualitative Research in Organizations and Management: An International Journal, 1(1), 4-12.

Charity Navigator. (2012). How do we rate charities? Retrieved from http://www.charitynavigator.org/inde x.cfm?bay $=$ content. view\&cpid $=1284$

Courtney, R. (2002). Strategic management for voluntary and non-profit organisations. London: Routledge

Crittenden, W. F., \& Crittenden, V. L. (2000).Relationships between organizational characteristics and strategic planning processes in nonprofit organizations. Journal of Managerial Issues, 12 (2), 150-169.

Crittenden, W. F., Crittenden, V. L., \& Hunt, T. G. (1988).Planning and stakeholder satisfaction in religious organizations. Journal of Voluntary Action Research, 17, 60-73.

David, F. R. (2011). Strategic management: Concepts and cases. Peaeson/Prentice Hall.
Drucker, P. (1974). Management: Tasks, responsibilities and practices. New York, NY: Harper \& Row.

Drucker, P. (1990). Managing the non-profit organisation. New York: Harper Collins

Edwards, J. R., \&Bagozzi, R. (2000).On the nature and direction of relationships between constructs and measures.Psychological Methods, 4, 155e174.European Economic and Social Committee. (2012). The social economy in the European Union. Brussels: Visits and Publications.

Eisenhardt, K. M., \& Martin, J. A. (2000). Dynamic capabilities: what are they?.Strategic management journal, $1105-1121$.

Eisinger, P. (2002). Organizational capacity and organizational effectiveness among street-level food assistance programs. Nonprofit and Voluntary Sector Quarterly, 31(1), 115-130.

Ekpe, E. O., Eneh, S. I., \&Inyang, B. J. (2015).Leveraging Organizational Performance through Effective Mission Statement.International Business Research, 8(9), 135.

Forbes, D., \&Seena, S. (2006). The value of a mission statement in an association of not-for-profit hospitals.International Journal of Health Care Quality Assurance, 19(5), 409e419.

Forehand, A. (2000). Mission and organizational performance in the healthcare

Gomes, R. C., \&Liddle, J. (2009). The balanced scorecard as a performance management tool for third sector organizations: the case of the Arthur Bernardes foundation, Brazil. BAR. Brazilian Administration Review, 6(4), 354-366.

Grønbjerg, K. A. (1998). Markets, politics, and charity: Nonprofits in the political economy. In W. W. 
Heymann, P. B. (1987). The politics of public management. New Haven, CT: Yale University Press.

Horton, D. (2003). Evaluating capacity development: experiences from research and development organizations around the world.IDRC.

Hunt, S. D., Sparkman, R. D., \& Wilcox, J. B. (1982). The pretest in survey research: issues and preliminary findings. Journal of Marketing Research, 62(3), 42e54.

Jarvis, C. B., Mackenzie, S. B., \&Podsakoff, P. M. (2003).A critical review of construct indicators and measurement model misspecification in marketing and consumer research.Journal of Consumer Research, 30(September), $199 \mathrm{e} 218$.

Jensen, M. C. (1998). Foundations of organizational strategy. Cambridge, MA: Harvard University Press.

Johari, F., Ab Aziz, M. R., Ibrahim, M. F., \& Ali, A. F. M. (2013). The Roles of Islamic Social Welfare Assistant (Zakat) for the Economic Development of New Convert. Middle-East Journal of Scientific Research, 18(3), 330-339.

Kaplan, R. (2001). Strategic performance measurement and management in nonprofit organizations.Nonprofit Management and Leadership, 11, $353 \mathrm{e} 370$.

Kaplan, R. S., \& Norton, D. P. (1996).The balanced scorecard. Boston: Harvard Business School Press.

Kasri, R. (2013). Giving Behaviors in Indonesia: Motives and Marketing Implications for Islamic Charities.Journal of Islamic Marketing, 4(3), 6-6.

Kendall, J., \& Knapp, M. (2000).Measuring the performance of voluntary organizations. Public Management Review, 2(1), 105-132.

Kirk, G., \& Nolan, S. B. (2010).Nonprofit mission statement focus and financial
performance.Nonprofit Management \& Leadership, 20(4), 473e490.

Leone, R. A. (1986). Who profits: Winners, losers, and government regulation. New York: Basic Books.

Macedo, I. M., \&Pinho, J. C. (2006). The relationship between resource dependence and market orientation: the specific case of non-profit organisations. European Journal of Marketing, 40(5/6), 533e553.

Macedo, I. M., Pinho, J. C., \& Silva, A. M. (2016).Revisiting the link between mission statements and organizational performance in the non-profit sector: The mediating effect of organizational commitment. European Management Journal, 34(1), 36-46.

Maududi, A.A. (1988), Maashiaati Islam, Islamic Publication, Lahore.

Miller, G., Dingwall, R., \& Murphy, E. (2004).«|" T Using qualitative data xi and analysis. Qualitative research: Theory, method and practice, 325 .

Moore, M. H. (1995). Creating public value: Strategic management in government. Cambridge, MA: Harvard University Press.

Moore, M. H. (2000). Managing for value: organizational strategy in for-profit, nonprofit, and governmental organizations.Nonprofit and Voluntary Sector Quarterly, 29(1), $183 \mathrm{e} 204$.

Morphew, C. C., \& Hartley, M. (2006). Mission statements: A thematic analysis of rhetoric across institutional type. The Journal of Higher Education, 77(3), 456-471.

Nunnally, J. (1978). Psychometric theory. New York, NY: McGraw-Hill.

Oghojafor, B. E. A., Olayemi, O. O., Okonji, P. S., \&Okolie, J. U. (2011). Enhancing Organization's Performance Through Effective Vision and Mission. Chinese Business Review, 10(11). 
Osborne, S. (1996). What is 'voluntary' about the voluntary and non-profit sector? In S. Osborne (Ed.), Managing the voluntary sector: A handbook for managers in charitable and non-profit organizations (pp. 5e17). London: International Thomson Press.

Osman-Gani, A. M., \&Sarif, S. M. (2011).Spirituality in Management from Islamic Perspective.

Oster, S. (1995). Strategic management for nonprofit organizations: Theory and cases. New York: Oxford University Press.

Oster, S. M. (1995). Strategic management for nonprofit organizations: Theory and cases. New York: Oxford University Press.

Pearce II, J. A. (1982). The company mission as a strategic tool. Sloan Management Review (pre-1986), 23(3), 15.

Peters, T. J., \& Waterman, R. H. (1982). In search of excellence: Lessons from America's best-run companies. New York: Warner.

Phills, J. (2005). Integrating mission and strategy for nonprofit organisations. New York: Oxford University Press.

Pock, A. (2007).Strategic management in Islamic finance.Springer Science \& Business Media.

Podsakoff P, Dalton, D. 1987. Research methodology in organizational studies. Journal of Management 13(2): 419-441

Porter, L., Steers, R., Mowday, R., \&Boulian, P. (1974). Organisational commitment, job satisfaction and turnover among psychiatric technics.Journal of Applied Psychology, 59, 603e609.

Porter, M. (1980).Corporate strategy. New York. New York, NY.

Porter, M. E. (1980). Competitive strategy. New York: Free Press.
Powell \& E. Clemens (Eds.), Private action and the public good (pp. 137-150). New Haven, CT:

Preacher, K. J., \& Hayes, A. F. (2008).Asymptotic and resampling strategies for assessing and comparing indirect effects in multiple mediator models. Behavior Research Methods, 40, ,879e,891.

Rarick, C., Vitton, J. (1995).Mission statements make cents. Journal of Business Strategy, 16, 11-12

Roberts, N., \&Tatcher, J. (2009). Conceptualizing and testing formative constructs: tutorial and annoted example. The Data Base for Advances in Infirmation Systems, 40, 9e13.

Salancik, G. (1977). Antecedents and outcomes of organisational commitment. Administrative Science Quarterly, 22(1), 46e56

Sargeant, A. (1999). Marketing Management for Nonprofit Organizations. Oxford: Oxford University Press.

Sargeant, A., \& Lee, S. (2004). Trust and relationship commitment in the United Kingdom voluntary sector: Determinants of donor behavior. Psychology and Marketing, 21(8), 613-635.

Sattari, S., Pitt, L. F., \&Caruana, A. (2011). How readable are mission statements? An exploratory study. Corporate Communications: An International Journal, 16(4), 282e292.

Sawhill, J. C., \& Williamson, D. (2001).Mission

impossible?Measuring success in nonprofit organizations.Nonprofit Management \& Leadership, 11(3), $371 \mathrm{e} 386$.

Schendel, D., \& Hofer, C. W. (Eds.). (1979). Strategic management: A new view of business policy and planning. Little, Brown.

Schlesinger, M., Mitchell, S., \& Gray, B. H. (2004). Restoring public legitimacy to 
the nonprofit sector: a survey experiment using descriptions of nonprofit ownership.Nonprofit and Voluntary Sector Quarterly, 33, $673 \mathrm{e} 710$.

Sheaffer, Z., Landau, D., \&Drori, I. (2008). Mission statement and performance: an evidence of 'coming of age'. Organization Development Journal, 26(2), 49e62.

Shrivastava, P. (1987). Rigor and practical usefulness of research in strategic management. Strategic Management Journal, 8(1), 77-92.

Siciliano, J. I. (2008). A comparison of CEO and director perceptions of board involvement in strategy.Nonprofit and Voluntary Sector Quarterly, 27, $152 \mathrm{e} 162$.

Siddiqi, M. N. (1988). The guarantee of a minimum level of living in an Islamic state. Distributive Justice and Need Fulfillment in an Islamic Economy, The Islamic Foundation, Leicester, 251-86.

Sidhu, J. (2003). Mission statements: is it time to shelve them? European Management Journal, 21(4), 439e446.

Smith, S. R., \&Lipsky, M. (1993). Nonprofits for hire: The new welfare state in the age of contracting. Cambridge, MA: Harvard University Press.

Steers, R. (1977).Antecedents and outcomes of organisational commitment.Administrative Science Quarterly, 22(1), 46e56.

Sufi, T., \& Lyons, H. (2003). Mission statements exposed. International Journal of Contemporary Hospitality Management, 15(5), 255e262.

Swales, J. M., \& Rogers, P. S. (1995). Discourse and the projection of corporate culture: The mission statement. Discourse \& Society, 6(2), 223-242.

Tober, J. (1991). Strategic planning in organizations and environments (working paper no. 165). New Haven, CT: Yale Program on Non-profit Organizations.

Weerawardena, J., Mcdonald, R. E., \& Sullivan-Mort, G. (2010). Sustainability of nonprofit organizations: an empirical investigation. Journal of World Business, 45, 346e 356.

Weissbrod, B. A. (1988). The nonprofit economy. Cambridge, MA: Harvard University Press. Wilson, J. Q. (1989). Bureaucracy: What government agencies do and why they do it. New York: Basic Books.

Wilson I. 1992. Realizing the Power of Strategic Vision. Long Range Planning 25(5): 18-28

Wolch, J. (1990). Planning as crisis management: An analysis of London's voluntary sector (working paper no. 147). New Haven, CT: Yale Program on Non-Profit Organizations

Wooldridge, B., \& Floyd, S. W. (1990). The strategy process, middle management involvement, and organizational performance.Strategic management journal, 11(3), 231-241.

Young, D. (1986). Executive leadership in nonprofit organizations. In W. W. Powell (Ed.), The Nonprofit Sector.

Rahmatina Awaliah Kasri

University of Indonesia

rahmatina@ui.ac.id

Niken Iwani Surya Putri

University of Indonesia

nikeniwanisuryaputri@gmail.com 